Hal.

\title{
FAKTOR-FAKTOR YANG MELATARBELAKANGI INTENSITAS TERAPI PERILAKU AUTISME METODE ABA (APPLIED BEHAVIOR ANALYSIS) PADA ANAK AUTIS DI RUMAH
}

\author{
Aisyah, Asmika, Nanik Setijowati \\ Fakultas Kedokteran Unibraw
}

\begin{abstract}
The Autism children in Indonesia had increased drastically every year. From HOPA's (Himpunan Orang tua Peduli Autisme) data, in Malang and surrounding area, there were 12 autism children in 2001, 98 children ini 2002 and increased to 120 children in June 2003. Major behavioral therapy centers in Indonesian are using ABA method for autism's therapy. The 3 intensity of ABA methode needs to apply at leas 40 hours a week to get on optimal result. However, in " $A$ - PLUS " Dharma Wanita Autistic Behavioral Therapy Center, the intensity of ABA methode didn't achieve the target. Thus the lack of time should be substitute by applying at home. The objective of the study is to observe the factors that influence the intensity of autistic behavioral therapy with ABA methode to the autismchildren a their home. This research is descriptive observational with cross sectional study using questionaire as instrument. The Study has been done 17 parents with autism children whom received behavioral therapy in "A-PLUS "Dharma Wanita Autistic Behavioral Therapy Center Kota Malang. It was held from June until August 2003 using quota sapling technique. The result of the intensity of ABA methode on autistic children at home is sufficient (47\%). The respondent's knowledge about autism and the treatment are good (59\%). The father's occupations are merchant (70\%) while the mother's are housewives (58\%). The incomes of the parets are more than 2 million rupiah monthly (59\%). Duration of respondent's dialy activity is more then six hours (53\%). Respondents families are extended family (65\%) with two children (65\%). Almost all respondent (82\%) are not participating in any autism organization in Malng. The study hows that the intensity of autism behavioral therapy with ABA method to autism children at home is mostly sufficient because the respondent's knowledge about autism and the treatment are good.
\end{abstract}

Key words: Autism, Autistic Behavioral Therapy, and ABA Method

\begin{abstract}
ABSTRAK
Jumlah anak penyandang autisme di Indonesia mengalami peningkatan yang drastis dari tahun ke tahun. Di Malang dan sekitarnya, dari data Himpunan Orang tua Peduli Autisme (HOPA) tahun 2001 tercatat 12 anak penyandang autisme, tahun 2002 terdaftar 98 anak dan pada bulan Juni 2003 tercatat 120 anak autis. Di Indonesia, terapi perilaku yang banyak dijalankan oleh pusat-pusat terapi untuk anak autis adalah ABA. Intensitas terapi perilaku ini mensyaratkan minimal 40 jam seminggu untuk mencapai hasil yang optimal. Tetapi intensitas terapi perilaku di Pusat Terapi Autisme 'A-Plus' Malang tidak mencapai angka tersebut, sehingga kekurangan dari jumlah waktu terapi bagi anak autis harus diberikan di rumah. Penelitian ini dimaksudkan untuk memperoleh gambaran tentang faktor-faktor yang melatarbelakangi intensitas terapi perilaku autisme metode ABA pada anak autis di rumah. Penelitian ini bersifat deskriptif observasional melalui pendekatan cross sectional study dengan instrumen penelitian berupa kuisioner. Responden sebanyak 17 orang tua dari anak penyandang autisme yang diterapi di pusat terapi autisme 'A-Plus' Dharma Wanita PUNM Kotamadya Malang mulai Juli 2003 sampai dengan Agustus 2003 yang diperoleh dengan teknik quota sampling. Didapatkan hasil intensitas terapi perilaku autisme metode ABA pada anak autis di rumah adalah cukup (47\%). Tingkat pengetahuan responden tentang autisme dan penanganannya baik (59\%). Pekerjaan ayah wiraswasta (70\%) dan ibu tidak bekerja (58\%). Penghasilan orang tua lebih dari 2 juta rupiah perbulan (59\%). Durasi aktivitas responden di luar rumah lebih dari 6 jam per hari (53\%). Struktur keluarga responden adalah extended family (65\%) dengan jumlah anak 2 orang (65\%). Hampir seluruh responden (82\%) tidak ikut serta dalam keanggotaan organisasi khusus autisme di Malang. Dari penelitian diperoleh gambaran bahwa intensitas terapi perilaku autisme metode $A B A$ pada anak autis di rumah sebagian besar cukup baik karena didukung oleh tingkat pengetahuan yang dimiliki responden tentang autisme dan penanganannya baik.
\end{abstract}

Kata kunci: Autisme, Terapi Perilaku Autisme, Metode ABA.

\section{PENDAHULUAN}

Anak harus tumbuh dan berkembang menjadi manusia dewasa yang baik yang bisa mengurus dirinya sendiri dan tidak bergantung atau menimbulkan masalah pada orang lain, pada keluarga atau masyarakatnya (1).

Tetapi suatu kenyataan yang tidak dapat dipungkiri bahwa adanya sejumlah anak yang memperlihatkan perilaku tidak wajar, bertingkah laku tidak sesuai dengan norma, baik norma budaya maupun norma sosial yang berlaku dalam lingkungan dimana anak berada, sehingga tingkah laku mereka ini biasanya lebih dirasakan oleh lingkungannya dari pada oleh anak sendiri (2).

Pembahasan mengenai anak dengan Gangguan Perkembangan atau Gangguan Pervasif (Autisme, Asperger

Maj. Kedok. Unibraw Vol. XIX, No.2, Agustus 2003 
Hal.

Syndrome, Rett Syndrome, dII) akhir-akhir ini sudah semakin informatif (3).

Autisme bukanlah penyakit menular, namun suatu gangguan perkembangan yang luas yang terjadi pada anak. Gejala muncul sebelum usia tiga tahun. Perkembangan yang terganggu adalah bidang komunikasi, interaksi sosial dan perilaku (4).

Pada tahun 1987 disebutkan 1: 5000 anak menunjukkan gejala autisme, sepuluh tahun kemudian tercatat 1: 500 anak. Bahkan tiga tahun kemudian angka ini meningkat menjadi 1: 150 anak, dan tahun 2001 yang lalu sudah mencapai 1: 100 anak (5). Di Malang dan sekitarnya, tahun 2001 tercatat 12 anak penyandang autisme, tahun 2002 bulan Februari yang terdaftar 98 anak dan pada bulan Juni 2003 tercatat 120 anak autis (Himpunan Orang tua Peduli Autisme-HOPA).

Terapi-terapi dan model pendidikan bagi anak-anak dengan gangguan perkembangan khususnya autisme mulai mendapat perhatian khusus dari para ahli (3). Di Indonesia, terapi perilaku yang banyak dijalankan oleh pusat-pusat terapi untuk anak autis adalah ABA (Aplied Behavior Analysis) yang mulai dipraktekkan pada tahun 1997 (6).

Kurikulum ABA terdiri atas lebih dari 500 tugas individual yang perlu dikerjakan, dan terapi berlangsung sekitar 2 tahun secara intensif dengan 40 jam per minggu (6). Persyaratan ini sangat sulit dipenuhi oleh para orang tua karena apabila akan dilakukan di sekolah, mereka terbentur pada masalah biaya yang besar. Bila akan dilakukan di rumah, mereka sendiri tidak mempunyai waktu yang cukup, karena masih ada anak-anak yang lain atau karena mereka harus bekerja mencari nafkah (7).

Dari majalah Nakita edisi Februari 2002 diketahui bahwa rata-rata klinik khusus yang menangani autisme di beberapa tempat di Jakarta hanya memberikan terapi 10 jam dalam setiap minggunya. Sisanya dilakukan di rumah oleh orang tua atau terapis. Berdasarkan wawancara dengan Dra. Indrawati, MEd selaku pimpinan pusat terapi autisme 'A-Plus' sekaligus anggota HOPA (Himpunan Orang tua Peduli Autisme) di Malang mengatakan bahwa rata-rata terapi yang diberikan untuk anak autis di tempat tersebut adalah 5 kali per minggu dimana setiap sesi berlangsung selama 2 jam. Jadi rata-rata 10 jam perminggunya. Dan yang lebih penting lagi, walaupun anak-anak autis sudah diterapi di pusat/tempat terapi, di rumah pun tetap dilatih, mengingat bahwa waktu yang dihabiskan di rumah tentu lebih banyak (8).

Jadi, dari data tersebut diatas dapat dikatakan bahwa intensitas terapi di pusat terapi autisme 'A-Plus' Malang tidak mencapai angka 40 jam per minggunya, sehingga kekurangan dari jumlah waktu terapi bagi anak autis harus diberikan di rumah, disamping itu waktu yang dihabiskan oleh anak autis lebih banyak di rumah. Sehingga penelitian ini bertujuan ingin mengetahui mengenai faktor-faktor yang melatarbelakangi intensitas terapi perilaku metode ABA bagi anak autis di rumah.

\section{METODOLOGI}

Metode yang digunakan deskriptif observasional dengan pendekatan cross sectional study untuk memperoleh data mengenai faktor-faktor yang melatarbelakangi intensitas terapi perilaku autisme metode ABA pada anak autis di rumah. Sebagai Populasi adalah semua orang tua dari anak-anak penyandang autisme yang menjalani terapi di Pusat Terapi Autisme 'A- Plus' Dharma Wanita PUNM Kotamadya Malang. Sampel dalam penelitian ini adalah semua orang tua (ayah atau ibu) dari anak penyandang autisme yang diterapi di Pusat Terapi Autisme 'APlus' Dharma Wanita PUNM Kotamadya Malang yang diperoleh dengan teknik quota sampling. Lokasi penelitian dilakukan di Pusat Terapi Autisme 'A-Plus' Dharma Wanita PUNM Kotamadya Malang. Waktu penelitian dilakukan mulai bulan Juli sampai dengan Agustus 2003.Instrumen Penelitian kuesioner tertutup dan terbuka yang diberikan secara langsung kepada reponden.

1. Data variabel pengetahuan dan intensitas Terapi perilaku yang terkumpul dilakukan tabulasi, kemudian diberikan skor pada jawaban responden. Jawaban ini diberi skor 1 sampai 5 . Diberi skor 0 bila responden tidak menjawab.

Untuk jawaban dari pertanyaan yang menanyakan tentang pendapat responden, dengan menggunakan skala Likert, pengolahannya menggunakan skoring dengan nilai:

$\mathrm{STS}=1 ; \mathrm{TS}=2 ; \mathrm{RR}=3 ; \mathrm{S}=4 ; \mathrm{SS}=5$

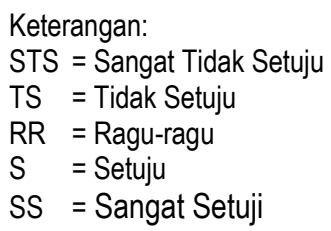

Untuk pertanyaan positif.

$\mathrm{STS}=5 ; \mathrm{TS}=4 ; \mathrm{RR}=3 ; \mathrm{S}=2 ; \mathrm{SS}=1$

Untuk pertanyaan negatif.

Selanjutnya dijumlahkan dan dibandingkan dengan skor tertinggi lalu dikalikan $100 \%$ dengan rumus:

$$
\mathrm{N}=\frac{\mathrm{Sp}}{\mathrm{Sm}} \times 100 \%
$$

Keterangan

$\mathrm{N}$ : Nilai yang didapat

Sp : Skor yang didapat

Sm : Skor tertinggi

Hasil pengolahan data berupa prosentase diinterpretasikan dengan kriteria kualitatif:
a. $76-100 \%=$ baik
b. $56-75 \%=$ cukup baik
c. $40-55 \%=$ kurang baik (9)

2. Data variabel aktivitas orang tua, struktur keluarga, dan organisasi khusus autisme yang terkumpul dilakukan tabulasi, kemudian dilakukan analisis data dengan distribusi frekuensi dan prosentase.

Nilai hasil prosentase kemudian diinterpretasikan dengan menggunakan skala:

$$
\begin{array}{ll}
0 \% & =\text { tidak satupun } \\
1-25 \% & =\text { sebagian kecil } \\
26-49 \% & =\text { hampir setengahnya } \\
50 \% & =\text { setengahnya } \\
51-75 \% & =\text { sebagian besar } \\
76-99 \% & =\text { hampir seluruhnya } \\
100 \% & =\text { seluruhnya (9) }
\end{array}
$$

Pengumpulan Data dilaksanakan dengan menggunakan teknik wawancara/kuisioner. 
Hal.

\section{HASIL PENELITIAN}

Pengambilan sampel dilakukan dengan teknik quota sampling di Pusat Terapi Autisme 'A-Plus' Dharma Wanita PUMN Kotamadya Malang dengan instrumen penelitian berupa kuesioner. Jumlah sampel yang diharapkan dari lokasi penelitian tersebut adalah sebanyak 29 responden, tetapi hingga akhir waktu pengumpulan kuesioner yang telah ditentukan ternyata hanya 17 responden yang mengumpulkan kuesioner, sehingga oleh peneliti 13 orang lainnya dianggap tidak memenuhi kriteria inklusi penelitian

Respondennya adalah para orang tua dari anak autis yang diterapi di pusat terapi autisme 'A-Plus' Malang dimana yang mengisi kuisioner terdiri dari ibu sebanyak 15 orang dan ayah 2 orang.

Hasil penelitian tentang faktor-faktor yang melatarbelakangi intensitas terapi perilaku autisme metode ABA pada anak autis di rumah adalah sebagai berikut:

Tabel 1. Distribusi Frekuensi Responden berdasarkan Karakteristik Responden

\begin{tabular}{|c|c|c|c|c|}
\hline Karakteristik responden & Ayah $n=17$ ) & & Ibu $(n=17)$ & \\
\hline & Frekuensi & $\%$ & Frekuensi & $\%$ \\
\hline $\begin{array}{l}\text { Pendidikan } \\
\text { a. S.D. }\end{array}$ & 0 & 0 & 0 & \\
\hline b. SLTP & 0 & 0 & 0 & 0 \\
\hline c. SLTA & 4 & 24 & 3 & 18 \\
\hline d. Diploma & 3 & 18 & 3 & 18 \\
\hline e.P.T & 10 & 58 & 11 & 64 \\
\hline Pekerjaan & & & & \\
\hline a. P.N & 2 & 12 & 1 & 6 \\
\hline b. B.U.M.N. & 0 & 0 & 1 & 6 \\
\hline c. Kary. Swasta & 3 & 18 & 1 & 6 \\
\hline d. Wiraswasta & 12 & 70 & 4 & 24 \\
\hline e. Tidak bekerja & 0 & 0 & 10 & 58 \\
\hline
\end{tabular}

Dari data diatas diperoleh gambaran karakteristik orang tua anak penyandang autisme yang menjadi responden dalam penelitian ini, yaitu:

- Sebagian besar responden ayah (58\%) berpendidikan terakhir di perguruan tinggi. Sedangkan sebagian besar responden ibu (64\%) juga berpendidikan terakhir di perguruan tinggi.

- Sebagian besar responden ayah (70\%) memiliki usaha sendiri (wiraswasta) sebagai mata pencahariannya. Untuk responden ibu, sebagian besar $(58 \%)$ adalah ibu rumah tangga tetapi hampir setengah yang lain (42\%) adalah ibu-ibu yang bekerja.

Tabel 2. Distribusi Frekuensi Responden berdasarkan Tingkat Pengetahuan Autisme dan Penanganannya

\begin{tabular}{|c|c|c|}
\hline Kategori & Frekuensi & $\%$ \\
\hline Baik & 10 & 59 \\
Cukup & 2 & 12 \\
Kurang & 5 & 29 \\
\hline Jumlah & 17 & 100 \\
\hline
\end{tabular}

Dari tabel 2 diperoleh gambaran bahwa sebagian besar tingkat pengetahuan responden tentang autisme dan penanganannya adalah baik (59\%).

Tabel 3. Distribusi Frekuensi Responden Berdasarkan Pengetahuan tentang Metode ABA

\begin{tabular}{|c|c|c|}
\hline Pengetahuan tentang metode ABA & Frekuensi & $\%$ \\
\hline Tahu & 14 & 82 \\
Tidak tahu & 3 & 18 \\
\hline Jumlah & 17 & 100 \\
\hline
\end{tabular}

Dari tabel 3 diperoleh gambaran bahwa hampir seluruh responden (82\%) mengetahui tentang metode ABA (Applied Behaviour Analysis). Hanya sebagian kecil responden (18\%) belum mengetahui tentang metode $A B A$.

Tabel 4. Distribusi Frekuensi berdasarkan Penghasilan Keluarga per Bulan

\begin{tabular}{|l|c|c|}
\hline \multicolumn{1}{|c|}{ Penghasilan per bulan } & Frekuensi & $\%$ \\
\hline <Rp. $1.000 .000,-$ & 0 & 0 \\
Rp. $1.000 .000-2.000 .000,-$ & 7 & 41 \\
> Rp. $2.000 .000,-$ & 10 & 59 \\
\hline & 17 & 100 \\
\hline
\end{tabular}

Dari tabel 4 diperoleh gambaran bahwa sebagian besar responden (59\%) memiliki penghasilan perbulan lebih dari Rp. 2.000.000,- dan hampir setengah responden (41\%) berpenghasilan antara Rp.1.000.000-2.000.000,- per bulannya.

Tabel 5. Distribusi Frekuensi Responden berdasarkan Ratarata Jumlah Jam untuk Aktivitas Sehari-hari di Luar Rumah

\begin{tabular}{|c|c|c|}
\hline Jumlah jam per hari & Frekuensi & $\%$ \\
\hline$<2$ & 7 & 41 \\
$3-5$ & 1 & 6 \\
$>6$ & 9 & 53 \\
\hline Jumlah & 17 & 100 \\
\hline
\end{tabular}

Dari tabel 5 diketahui bahwa sebagian besar reponden (53\%) menghabiskan waktu rata-rata lebih dari 6 jam per harinya untuk aktivitas sehari-hari di luar rumah. Hampir setengah responden (41\%) yang menghabiskan kurang dari 2 jam per hari dan hanya 1 responden yang memakai 3-5 jam untuk aktivitas sehari-harinya.

Tabel 6. Distribusi Frekuensi berdasarkan Hubungan Kekerabatan yang Tinggal Serumah dengan Responden

\begin{tabular}{|l|c|c|}
\hline Hubungan kekerabatan & Frekuensi & $\%$ \\
\hline Nuclear family & 6 & 35 \\
Extended family & 11 & 65 \\
\hline \multicolumn{1}{|c|}{ Jumlah } & 17 & 100 \\
\hline
\end{tabular}

Dari tabel diatas diperoleh gambaran bahwa hubungan kekerabatan responden sebagian besar (65\%) adalah extended family. 
Hal.

Tabel 7. Distribusi Frekuensi berdasarkan Jumlah Anak Responden

\begin{tabular}{|c|c|c|}
\hline Jumlah anak & Frekuensi & $\%$ \\
\hline 1 & 2 & 12 \\
2 & 11 & 65 \\
$>2$ & 4 & 23 \\
\hline Jumlah & 17 & 100 \\
\hline
\end{tabular}

Dari tabel 7 diatas diperoleh gambaran bahwa sebagian besar responden (65\%) memiliki 2 anak.

Tabel 8. Distribusi Frekuensi berdasarkan Jumlah Jam Terapi Anak Autis per Minggu di Tempat Terapi

\begin{tabular}{|c|c|c|}
\hline Jumlah jam per minggu & Frekuensi & $\%$ \\
\hline$\leq 10$ & 10 & 59 \\
$>10$ & 7 & 41 \\
\hline Jumlah & 17 & 100 \\
\hline
\end{tabular}

Dari tabel 8 diketahui bahwa sebagian besar dari anak autis responden diterapi selama kurang dari atau sama dengan 10 jam per minggu (59\%) di tempat terapi.

Tabel 9. Distribusi Frekuensi berdasarkan Keberadaan Terapis di Rumah

\begin{tabular}{|c|c|c|}
\hline Keberadaan terapis & Frekuensi & $\%$ \\
\hline Ada & 3 & 18 \\
Tidak ada & 14 & 82 \\
\hline Jumlah & 17 & 100 \\
\hline
\end{tabular}

Dari tabel diatas dapat diketahui bahwa hampir seluruh responden (82\%) tidak mendatangkan terapis ke rumah. Hanya sebagian kecil responden (18\%) yang memanggil terapis untuk melatih anak autis di rumah.

Tabel 10.Distribusi Frekuensi berdasarkan Keberadaan Terapis Memberikan Latihan di Rumah dalam Jam per Minggu

\begin{tabular}{|c|c|c|}
\hline Jumlah jam per minggu & Frekuensi & $\%$ \\
\hline$<4$ & 1 & 33 \\
$5-6$ & 2 & 67 \\
\hline Jumlah & 3 & 100 \\
\hline
\end{tabular}

Tabel diatas menunjukkan bahwa dari 3 responden yang mendatangkan terapis ke rumah, 2 diantaranya menyatakan bahwa jumlah jam terapi yang diberikan oleh terapis berkisar 5-6 jam per minggunya dan responden yang lain hanya memberikan kurang dari 4 jam waktu bagi terapis untuk melatih anak autis di rumah.

Tabel 11. Distribusi Frekuensi berdasarkan Pendamping Anak Autis di Rumah Setiap Harinya

\begin{tabular}{|l|c|c|}
\hline \multicolumn{1}{|c|}{ Pendamping } & Frekuensi & $\%$ \\
\hline Ayah & 1 & 6 \\
Ibu & 10 & 59 \\
Lain-lain* & 6 & 35 \\
$\begin{array}{l}\text { Ket*:anggota keluarga yang lain, suster/baby } \\
\text { sister, pembantu. }\end{array}$ & & \\
\hline \multicolumn{1}{|c|}{ Jumlah } & 17 & 100 \\
\hline
\end{tabular}

Dari tabel diatas dapat dilihat bahwa sebagian besar responden (59\%) yang mendampingi anak autis di rumah setiap harinya adalah ibu.

Tabel 12.Distribusi Frekuensi berdasarkan Intensitas Terapi Perilaku Autisme di Rumah

\begin{tabular}{|c|c|c|}
\hline Kategori & Frekuensi & $\%$ \\
\hline Baik & 2 & 12 \\
Cukup & 8 & 47 \\
Kurang & 7 & 41 \\
\hline Jumlah & 17 & 100 \\
\hline
\end{tabular}

Tabel diatas menunjukkan bahwa hanya sebagian kecil responden (12\%) yang melakukan intensitas latihan di rumah dengan baik. Hampir setengah responden menerapkan intensitas latihan dengan kategori cukup (47\%) dan kurang (41\%).

Tabel 13. Distribusi Frekuensi Jumlah Jam per Hari berdasarkan Materi Latihan yang Diberikan Pendamping pada Anak autis di Rumah

\begin{tabular}{|c|c|c|c|c|c|c|}
\hline \multirow{2}{*}{$\begin{array}{c}\text { Jjam/hari } \\
\text { materi } \\
\text { latihan }\end{array}$} & \multicolumn{2}{|c|}{$\leq 4$} & \multicolumn{2}{c|}{$>4$} & \multicolumn{2}{c|}{ Jumlah } \\
\cline { 2 - 7 } & Frek & $\%$ & Frek & $\%$ & Frek & $\%$ \\
\hline Baik & 0 & 0 & 2 & 12 & 2 & 12 \\
\hline Cukup & 2 & 12 & 6 & 35 & 8 & 47 \\
\hline Kurang & 2 & 12 & 5 & 29 & 7 & 41 \\
\hline Jumlah & 4 & 24 & 13 & 76 & 17 & 100 \\
\hline
\end{tabular}

Dari tabel diatas diperoleh gambaran bahwa hanya sebagian kecil responden (12\%) yang menerapkan latihan di rumah dengan kategori baik kepada anak autis. Hampir setengah responden menjawab bahwa mereka menerapkan latihan dengan kategori cukup (47\%).

Sedangkan untuk jumlah jam pendamping, hampir seluruh responden $(76 \%)$ mengatakan bahwa mereka mendampingi anak di rumah lebih dari 4 jam.

Tabel 14. Distribusi Frekuensi berdasarkan Keikutsertaan Responden dalam Organisasi Khusus Autisme

\begin{tabular}{|c|c|c|}
\hline Ikut serta & Frekuensi & $\%$ \\
\hline Ya & 3 & 18 \\
Tidak & 14 & 82 \\
\hline Jumlah & 17 & 100 \\
\hline
\end{tabular}

Dari tabel 14 diketahui bahwa hampir seluruh responden (82\%) tidak ikut serta dalam suatu keanggotaan dari perkumpulan orang tua anak penyandang autisme. Hanya sebagian kecil responden (18\%) mengaku ikut dalam keanggotaan tersebut.

\section{PEMBAHASAN}

Gambaran Karakteristik Responden. Dari tabel 1 diperoleh gambaran bahwa sebagian besar responden memiliki tingkat pendidikan yang tinggi yaitu lulusan perguruan tinggi (ayah $=58 \%$, ibu=64\%). Hal ini berarti tidak sulit bagi responden untuk mencari informasi tentang autisme dan penanganannya (3).

Maj. Kedok. Unibraw Vol. XIX, No.2, Agustus 2003 
Hal.

Seluruh ayah dalam penelitian ini bekerja dengan bidang pekerjaan sebagian besar $(70 \%)$ adalah wiraswasta. Hal ini tentunya akan mengurangi waktu interaksi mereka dengan anak autis di rumah. Sehingga dituntut waktu lebih banyak dari ibu untuk mendampingi anak di rumah (7) Sebagian besar ibu dalam penelitan ini adalah ibu rumah tangga (58\%). Bahkan ada diantara mereka yang meninggalkan pekerjaanya karena anak autis perlu mendapat perhatian khusus (10). Sehingga mereka diharapkan dapat menyediakan waktu untuk mendampingi anak di rumah (7).

Gambaran Tingkat Pengetahuan Responden tentang Autisme dan Penanganannya. Dari tabel 2 diketahui bahwa tingkat pengetahuan responden tentang autisme dan penanganannya sebagian besar adalah baik (59\%). Hal ini tentunya akan memudahkan responden untuk mencari dan memahami informasi tentang autisme dan akan cukup terbuka tehadap perkembangan yang ada. Hal ini bisa berdampak sampai sebesar $80 \%$ pada kemajuan terapi anak (3).

Hampir seluruh responden $(82 \%)$ mengetahui tentang metode $A B A$ yang diterapkan kepada anak mereka di tempat terapi autisme 'A-Plus' Malang. Dan hampir seluruhnya juga mengetahui bahwa yang menunjang keberhasilan terapi autisme dangan metode $A B A$ adalah jika dilakukan secara intensif di tempat terapi dan di rumah. Akan tetapi setengah dari responden juga beranggapan bahwa penanganan oleh banyak ahli yang profesional juga termasuk penunjang keberhasilan dalam metode ABA. Hal ini kurang tepat oleh karena penunjang keberhasilan dalam metode $A B A$ yaitu pelaksanaan yang intensif, optimal dan pada usia dini (6). Kemitraan orang tua dengan para ahli (psikiater, psikolog, orthopaedagog) hanya merupakan program yang dapat membantu optimalitas penerapan intervensi pada anak autis (11).

Gambaran Penghasilan Keluarga Responden. Sebagian besar responden memiliki penghasilan keluarga lebih dari 2 juta rupiah per bulannya (59\%). Hal ini tentu akan memberi kesempatan untuk mendapatkan penanganan sebaik mungkin bagi anak autis. Walaupun sebagian besar pendapatan keluarga responden lebih dari 2 juta per bulannya, dalam beberapa penelitian, para orang tua merasakan beban yang berat dalam membiayai pendidikan khusus, baik di tempat terapi/ sekolah maupun di rumah. Hal ini tampaknya dipengaruhi oleh makin berkembangnya informasi tentang cara-cara penanganan gangguan autis sehingga orang tua cenderung ingin mengikuti lebih banyak cara untuk 'menyembuhkan' anaknya (7).

Gambaran Aktivitas Sehari-hari Responden. Sebagian besar responden (53\%) yang dalam hal ini adalah ibu dari anak autis menghabiskan waktu lebih dari 6 jam perharinya untuk aktivitas sehari-hari di luar rumah. Ini bisa disebabkan karena hampir setengah responden ibu adalah wanita yang bekerja. Hal ini akan membatasi waktu interaksi antara sang ibu dengan anak di rumah $(7,10)$.

Gambaran Struktur Keluarga Responden. Dari tabel 6 diketahui bahwa hubungan kekerabatan yang tinggal serumah dengan anak autis adalah extended family (65\%). Menurut Wardhani, besaran anggota keluarga turut mempengaruhi pola penanganan anak dengan problematika autisme (11). Didalam extended family akan dijumpai anggota keluarga lain yang turut tinggal serumah dengan anak autis. Orang serumah yang seringkali menjadi penghalang adalah nenek dari anak tersebut. Meskipun banyak juga dijumpai para nenek yang justru ikut mendorong dan memberikan semangat untuk para orang tua anak agar segera menerapi anaknya dengan intensif. Para nenek yang menjadi penghalang biasanya adalah para nenek dominan yang sulit memahami tentang kelainan perilaku ini. Mereka menganggapnya hanya sebagai kenakalan biasa saja. Kelambatan bicara bukanlah hal aneh bagi mereka, oleh karena banyak anak mereka yang mengalami kelambatan bicara. Tapi orang lain yang serumah juga perlu diwaspadai dan kalau perlu juga diberi informasi yang cukup tentang kelainan ini (7).

Dari tabel 7 diketahui bahwa hampir seluruh responden $(88 \%)$ memiliki anak lebih dari 1 orang. Hal ini akan mempengaruhi besarnya perhatian yang diberikan oleh orang tua kepada anak autis maupun anggaran dana keluarga yang harus dikeluarkan untuk mencapai kesembuhan anak autis itu sendiri. Semakin banyak jumlah anak maka perhatian orang tua harus terbagi-bagi kepada seluruh anak tersebut. Sedangkan anggaran dana keluarga untuk anak yang lebih dari 1 orang akan lebih besar daripada keluarga dengan 1 anak (3).

Gambaran Intensitas Terapi Perilaku Autisme di Tempat Terapi. Sebagian besar dari responden $(59 \%)$ menerapi anak autis di tempat terapi kurang dari atau sama dengan 10 jam per minggu. Hal ini menunjukkan bahwa intensitas terapi perilaku di tempat terapi tidak mencapai angka 40 jam seminggu. Sehingga kekurangan jam tersebut harus dipenuhi di rumah.

Tetapi pada realitanya banyak orang tua anak dengan kebutuhan khusus seperti autisme menyerahkan (penanganan) anaknya "pasrah penuh" kepada institusi pusat terapi atau sekolah khusus. Mereka tidak mau tahu lagi dengan urusan pendidikan anaknya, cukup menyediakan biaya dan sarananya saja. Hal ini akan sangat merugikan dan sangat menghambat kemajuan terapi (7)

Gambaran Intensitas Terapi Perilaku Autisme di Rumah. Hampir seluruh responden (82\%) tidak mendatangkan terapis untuk menerapi anak di rumah. Hanya sebagian kecil saja $(18 \%)$ yang mendatangkan terapis ke rumah, itupun dengan intensitas terapi yang kurang dari 30 jam tiap minggunya. Hal ini bisa dimaklumi oleh karena biasanya kebutuhan dana untuk terapi di rumah jauh melebihi dari terapi di sekolah khusus. Terapis lepas biasanya menetapkan biaya terapi per jam dan mereka juga menuntut biaya transportasi. Kelangkaan terapis yang handal masih sulit didapat, sehingga mereka menetapkan harga yang tinggi (7).

Sebagian besar responden menyebutkan bahwa yang mendampingi anak autis di rumah setiap harinya adalah ibu $(59 \%)$. Karena memang seharusnya para orang tua terutama para ibu menyediakan waktu, pikiran dan tenaga untuk melakukan terapi sendiri bagi anaknya. Hal ini akan sangat mendukung terapi bagi anak autis jika para ibu mengerti teori tentang autisme dan metode ABA serta cukup terampil dalam berinteraktif dengan anak. Dan disiplin dalam metode ABA juga harus mampu dilakukan oleh orang yang yang bersinggungan dengan anak baik sebagai terapis ataupun hanya sebagai anggota keluarga (7).

Mayoritas responden menerapkan intensitas terapi perilaku dengan kategori cukup. Hanya sebagian kecil responden yang menerapkan intensitas terapi perilaku autisme di rumah 
Hal.

dengan kategori baik. Hal ini dapat disebabkan oleh ketidakpahaman responden ataupun pendamping anak tentang materi apa yang harus diberikan kepada anak autis dan bagaimana kemampuan anak dalam menyerap materi yang diajarkan, selain kurang terampilnya responden ataupun pendamping dalam berinteraktif dengan anak (7). Hal ini didukung dengan bukti dari tabel 13 yang menunjukkan bahwa hanya $12 \%$ responden yang memiliki kategori materi latihan baik. Jadi walaupun para orang tua terutama ibu mendampingi anak di rumah dalam jangka waktu cukup lama (lebih dari 4 jam per hari) tetapi mereka tidak menerapkan materi latihan yang sesuai konsep terapi perilaku metode ABA dengan baik. Sebab bukan hanya jumlah jam yang disediakan untuk intervensi yang penting, tetapi penting juga apa yang dikerjakan selama waktu tersebut. Seorang terapis atau orang tua yang terampil mungkin dapat menghasilkan lebih banyak kemajuan pada anak dalam 10 jam dibanding individu yang kurang terampil yang dikerjakan dalam 30 waktu jam dengan anak yang sama (6).
Gambaran Keikutsertaan Responden dalam Organisasi Khusus Autisme. Tabel 14 memberi gambaran bahwa hampir seluruh responden (82\%) tidak ikut serta dalam suatu keanggotaan organisasi khusus autisme. Sebagian diantara mereka menyebutkan bahwa alasan ketidakikutsertaan mereka oleh karena di Malang organisasi seperti itu tidak ada. Padahal berdasarkan wawancara dengan Dra. Indrawati, M.Ed selaku pimpinan pusat terapi autisme 'A-Plus' dan anggota HOPA, mengatakan bahwa sebetulnya organisasi semacam itu ada yaitu Himpunan Orang tua Peduli Autisme (HOPA). Jadi sebetulnya responden belum mengetahui keberadaan organisasi khusus autisme di Malang.

\section{KESIMPULAN :}

Gambaran bahwa intensitas terapi perilaku autisme metode $A B A$ pada anak autis dirumah sebagian besar cukup baik hal ini didukung oleh tingkat pengetahuan yang dimiliki responden tentang autisme dan penanganannya baik.

\section{DAFTAR KEPUSTAKAAN}

1. Gunarsa, S., Teori Perkembangan Anak. Jakarta: BPK Gunung Mulia. 1980.

2. Staf Pengajar IImu Kesehatan Anak. Buku Kuliah IImu Kesehatan Anak. Jakarta: Info Medika. 1985.

3. Chandra, T., Membantu Orang tua dalam Menangani dan Mendidik Anak dengan Gangguan Perkembangan Pervasif. Spectrum Treatment and Education Center. (online), (http://www.spectrum-autism.com, diakses 19 Maret 2002).

4. Sutady, R., Autisme: Gangguan Perkembangan Pada Anak. Dibacakan di Simposium Autisme. Yayasan Autisme Indonesia. Jakarta. 1997.

5. Kurnasih, D., dan Koesworini E., Menangani Anak autis. Nakita edisi Februari. Jakarta: PT Gramedia. 2002.

6. Sutady, R., Seminar dan Pelatihan Autisme 2 Hari. Jakarta: Lembaga Intervensi Terapan Autisme. 2000.

7. Handoyo, Y., Autisma-Petunjuk Praktis Pedoman Materi untuk Mengajar Anak Normal, Autis dan Perilaku Lain. Jakarta: PT. Bhuana IImu Populer. 2003.

8. Indrawati, Hendarto, Y.E., Kiat Membimbing Anak Autis. Makalah disajikan dalam Seminar Mampersiapkan Anak Penyandang Autis Hidup Mandiri. Malang. 6 April 2003.

9. Roesmana, J., Siregar, U., Terapi Baru Autisme. Femina, no. 29/XXX 18-24 Juli, 2002: 91

10. Arikunto, Suharsini. Prosedur Penelitian Suatu Pendekatan Praktek. Jakarta: Rineka Cipta. 1998.

11. Kompas. 22 November 1999. Pengalaman Orang tua Memenangkan Anak Autis, (Online), (http:www.handoko.net/keluarga.org/autisme.shtml, diakses 31 Maret 2002).

12. Buku Saku Diagnosis Gangguan Jiwa rujukan Ringkas dari PPDGJ III. Dalam Maslim R (Ed.). Jakarta. 2001.

13. Yuniar, S., Gangguan Spektrum Autisme dan Kiat Menanggulanginya. Makalah dibacakan dalam Seminar Maempersiapakan Anak Penyandang Autisme Hidup Mandiri. Malang. 6 April 2003.

14. Diagnostik and Statistical Manual of Mental Disorders. American phychiatric Assosiation. Washington DC. 1994.

15. Sutady, R., Autisme?! Apakah itu?. Buletin Autisme. Yayasan Autisme Indonesia. Jakarta, 1999.

16. Anonymous. Mengenal Autisme. (Online), (htttp://www.iqeq.web.id/art/art0.5.shtml, diakses 14 Maret 2002)

17. Indrawati. Deteksi Dini Autisme. Pimpinan Pusat Terapi Autisme "A-Plus" Dharma Wanita PUNM Kotamadya Malang. Malang. 2000.

18. Anonymous. Keunikan Autisme. (Online) (http://www.puterakembara.org/sebab.shtml, diakses 9 Maret 2002)

19. Anonymous, Pendidikan Khusus Bagi Anak dengan Gangguan Perkembangan. Spectrum Treatment and Education Center. (Online), (http://www.spectrum-autism.com, diakses 19 Maret 2002)

20. Hurlock, Elizabeth, H., Perkembangan Anak. Jilid 2. Jakarta: Penerbit Erlangga. 1989.

21. Notoadmodjo, Soekidjo. Metodologi Penelitian Kesehatan. Jakarta: Rineka Cipta. 1993.

22. Ginanjar, A.S., Wardhani, E.R., Towards A Better Life for Autistic Individual. Makalah dibacakan dalam Konferensi Nasional Autisme I. Jakarta, 2-4 Juli 2003.

23. Machmud, Rander. Pelaksanaan Holistic Autisme. Makalah dibacakan dalam Kongres Nasional Autisme Indonesia Pertama. Pusat Informasi dan Penelitian FKUI. Jakarta, 3 Mei 2003.

24. Ahmadi, A., Psikologi Sosial. Jakarta: PT. Rineka Cipta. 1991. 